\title{
NATO'S DEFENCE POLICY DILEMMA IN THE BALTIC STATES
}

\section{Lukas MILEVSKI, PhD}

Leiden University, Leiden, Netherlands

I.milevski@hum.leidenuniv.nl

\begin{abstract}
The purpose of this paper is to discuss the dilemma NATO has faced since February 2014 in its defence policy regarding the Baltic States. If NATO pursues a policy of deterrence, it might trigger war because Russia, the would-be deteree, may perceive actions taken by NATO as not intended to strengthen deterrence but rather to intimidate or coerce it. If it pursues an alternate policy of leaving the Baltic States visibly undefended, it might trigger war because Russia may see this as a sign of weakness and a gap to be exploited. This article investigates the logic of the dilemma, before considering whether NATO's choice, made at the Warsaw Summit of July 2016, is working as intended. Ultimately, we cannot predict the answer and, therefore, we should consider all possible outcomes, including those which lead to a defensive war in the Baltic States.
\end{abstract}

Key words: NATO, Russia, Baltic, defence policy, deterrence, Warsaw Summit

\section{Introduction}

Since its February 2014 aggression in Crimea and later in the Donbas, Russia, in one fell swoop, suddenly became the primary potential danger to NATO, particularly to the Baltic States, NATO's easternmost and most vulnerable constituents. NATO's response to the new security environment began as offering reassurance to eastern Europe before finally transitioning to deterrence for the purposes of 
precluding war. Since Crimea, NATO has moved from a policy of reassurance to one of deterrence. It has been evident that throughout these important policy debates and changes, NATO has been suffering from a dilemma concerning Baltic defence which is unlikely to be resolved in any immediately obvious way.

This article analyses the unenviable defence dilemma which NATO faces - that NATO is unlikely to influence the Kremlin in the exact direction it desires. Any defence policy decision which NATO may make-and that policy's subsequent implementation-may spark war as easily as it might prevent it. This is true of the deterrent policies which NATO has now chosen to pursue. It is also true of the policy option of leaving the Baltic States militarily undefended, which has had some support throughout the whole debate. Whether it consciously recognised this dilemma or not, NATO made its policy choice in July 2016 and its implementation has begun. The consequences of this choice are still developing and may yet be sent awry by President Donald Trump. Furthermore, the article examines whether NATO's choice currently appears to be having the desired effect, as well as the shape of a prudent course for the future.

\section{Deterrence for the Baltic States}

In mid-2015, RUSI Journal published an article of make-believe future history which hypothesised the conduct of a fictional war between NATO and Russia in Estonia. An important revelation within its text was the supposition that there was a war-that NATO did ultimately, despite some soul-searching and ungentle alliance diplomacy, go to war over one of its smallest constituents. In this scenario, NATO forces match their Russian counterparts but do not push home a military victory, even one limited to Estonia, in favour of a negotiated peace in which Russia is not required to sacrifice much face and which gives up to Russia many of its other foreign policy goals. Planted by the US government, as is clear from the author's initial authorship statement, the article's purpose was to send a message of deterrence to Moscow by asserting that NATO and its constituents had the 
individual and collective political will to wage a war against Russia should the alliance be militarily challenged ${ }^{1}$.

Yet deterrence cannot be practiced. 'To deter' is grammatically correct but strategically unsound. Deterrence is but an important side effect of one's own capabilities, posture, strategy, and policy, run through the prism of the opponent's perception and decision-making. "[D]eterrence is inherently unreliable...Quite literally, deterrence can work only if the intended deterree chooses to be deterred. There is no way in which such a choice, for deterrence, can be guaranteed." There is no logical method by which deterrence may be reliably induced in general, and perhaps not even in specific contexts. An adversary may always decline to be deterred and prefer to gamble policy outcomes on the wages of battle. Yet even this presupposes that both sides of the would-be deterrence relationship recognise it as such and not as a different kind of relationship altogether. NATO cannot guarantee today that Russia will consider its efforts to strengthen the defences of the Baltic States to be a measure aimed at improving deterrence.

One of Vladimir Putin's role models is Yuri Andropov, head of the KGB for fifteen years before taking over as premier of the Soviet Union in 1982. The most notable event of Andropov's fifteen-month tenure in this latter office occurred in November 1983-the Able Archer incident. An escalating sense of crisis in the Kremlin over previous years-fuelled by, among other external factors, US Presidential Directive 59, which reoriented US nuclear strategy toward a countervailing concept; early Reaganite rhetoric; the announcement of the Strategic Defense Initiative; and the United States' pending deployment of intermediate ranged nuclear forces to Europe-climaxed during NATO's annual Able Archer military exercises of 1983, nearly resulting in a potential pre-emptive Soviet nuclear strike against NATO targets. These US initiatives cumulatively had begun to weigh on and induce paranoia among the Soviet political leadership, not necessarily shared by the military hierarchy even one level below the Russian Chief of the General Staff, Nikolai Ogarkov3. “The reaction in Moscow [to recent prior events] was predictably

1 R.D. Hooker Jr., Operation Baltic Fortress, 2016, RUSI Journal , 3(160), 2015, pp. 26-36.

2 C.S. Gray, Deterrence and the nature of strategy, Small Wars \& Insurgencies, 2(11), 2000, p. 20.

3 G.S. Barrass, The Great Cold War: A Journey Through the Hall of Mirrors, Stanford, 2009, pp. 300-301. 
negative, but unpredictably hysterical."4 It was even fuelled by the Kremlin itself, as it sought to shift domestic attention away from the Soviet's mistaken downing of the KAL 007 airliner and Reagan's vociferous condemnation which followed ${ }^{5}$.

NATO considered the purpose of the Able Archer exercises to be the strengthening of deterrence, and Moscow was familiar with the exercises as they had been conducted annually. However, various anomalies in NATO's procedures for Able Archer in 1983 set Moscow on edge, including a higher than normal level of alert in US bases around the Soviet Union and the inclusion of civilian policymakers. The unexpected presence of civilian decision-makers was particularly significant. Not only had they never been involved in the Able Archer exercises before, but due to their involvement, NATO could now escalate the exercise up to the simulated release of nuclear weapons rather than stopping short of civilian, i.e. political, decision-making levels. In the climate of paranoia that permeated the Kremlin, these seemed to be grave indications of NATO's intention to launch a first nuclear strike.

NATO's intended reinforcement of deterrence failed in this case because the Soviet leadership did not recognise in the policies and decisions the intent to deter, but instead saw the intention to attack. In part, this was due to linguistic and conceptual differences which existed in Soviet strategic thinking. "For their deterrence of the West, the Soviets most commonly use the word sderzhivaniye (restraining); for Western deterrence of them they use the word ustrasheniye, which comes very close to meaning 'intimidation."' ${ }^{\prime}$ The Soviet leadership did not view their relationship with NATO as being a basic two-way deterrent relationship. They believed they were deterring NATO, which in turn was trying to intimidate the Soviet Union. Unlike Western strategists, the Soviets did not acknowledge the idea of mutual deterrence. The fundamental premise which must underlie all thinking about deterrence is recognition that the opponent one hopes to deter

4 S.J. Cimbala, Revisiting the Nuclear 'War Scare' of 1983: Lessons Retro- and Prospectively, Journal of Slavic Military Studies, 2(27), 2014, p. 238.

5 V. Mastny, How Able was 'Able Archer'?Nuclear Trigger and Intelligence in Perspective, Journal of Cold War Studies 1(11), pp. 117-121.

6 G. Jukes, The Military Approach to Deterrence and Defense in: M. McGwire, K. Booth, J. McDonnell, Soviet Naval Policy: Objectives and Constraints, New York, 1975, p. 484. 
may not believe that one is trying to deter him at all, but instead forcefully to intimidate or compel him?

Returning to the present day, current Russian rhetoric conveys the same pattern of thought as that which reigned in 1983. Even before his third term as President, Putin invoked the analogy of the Second World War to justify significant military modernisation and reform. "We cannot afford to repeat the tragedy of 1941, when the lack of readiness of the state and the Army for war led to the vast loss of human lives." Russian General Yuri Yakubov has suggested that "[i]f heavy U.S. military equipment, including tanks, artillery batteries and other equipment really does turn up in countries in eastern Europe and the Baltics, that will be the most aggressive step by the Pentagon and NATO since the Cold War." The Russians have publicly stated that NATO deployments to the Baltic States would be regarded as aggressive actions-not as moves meant to reinforce deterrence. The Russians, after all, also regard the colour revolutions which occurred in Georgia, Kyrgyzstan, and Ukraine as American-backed coups and fear that the West is conspiring to bring about a coup or revolutionary violence in Russia as well ${ }^{10}$. In an interesting historical parallel, the Soviet Union also feared the presence of German troops in the Baltic States during the interwar period, and the scenario of a German-led Baltic regional alliance against the Soviet Union dominated Soviet war plans during the period ${ }^{11}$. Russian rhetoric, directed to both international and domestic audiences, therefore conveys an important message about their perceptions. Whether these messages are truthful or not is a separate question, but they are officially and vociferously publicised domestically and internationally. Russia, in its previous incarnation as the Soviet Union, has in fact previously felt threatened by similar configurations of power in the Baltic region.

7 L. Milevski, Deterring Able Archer: Comments Arising from Adamsky's Lessons for Deterrence Theory and Practice, Journal of Strategic Studies 37(6-7), 2014, pp. 1060-1061.

8 V. Putin, Being strong: National security guarantees for Russia, 29 February 2012, http:// archive.premier.gov.ru/eng/events/news/18185/, [accessed: 28.10.2015].

9 Quoted in: G. Baczyńska, W. Szary, Russia says will retaliate if U.S. weapons stationed on borders, Reuters, 15 June 2015, http://www.reuters.com/article/2015/06/15/us-russia-usaeurope-idUSKBN0OV17A20150615, [accessed: 28.10.2015].

10 I. Bērzinna, Color revolutions: Democratization, Hidden Influence, or Warfare?, Riga, 2014, pp. 9-12.

11 G. Åselius, Soviet Naval Perceptions of the Baltic Sea, 1938-41 in: M. H. Clemmesen, M. S. Faulkner (eds), Northern European Overture to War, 1939-1941: From Memel to Barbarossa, Leiden, 2013, p. 94. 
Rather than deterrence, Russia's prisms for judging NATO's decisions concerning the defence of the Baltic States may well be intimidation, compellence, surprise attack, and coup. Given such a perspective, Russia's logical ultimate response to a major NATO deployment in the Baltic States is clear: pre-emption. Fortunately for a NATO policy emphasising deterrence, other, less radical options also exist for Russia to safeguard itself from another devastating war and to protect its selfimage as a great power, including continued reinforcement of Russia's western military district. Yet pre-emption will remain the ultimate policy option. Actions by NATO's councils and capitals, meant to deter the Russians from engaging in any invasive activities in the Baltic States and, by extension, from war in that theatre, may actually invite the Russians to do precisely those things because Russian perspectives diverge so fundamentally from NATO outlooks.

NATO's chosen policy of seeking to reinforce deterrence may result in the intended effect, or it may result in the opposite effect. This is one horn of the dilemma which NATO has faced since the Russian occupation of Crimea in February/March 2014 with regard to the defence of the Baltic States.

\section{Baring the Baltic States}

If the above analysis is apt and major deployments to the Baltic States trigger the war they were meant to prevent, then would it be a wiser policy option to leave the Baltic States bare and bereft of a present-on-their-soil collective NATO defence? Not necessarily. As Putin related to Charlie Rose on CBS' 60 Minutes, he considered the collapse of the Soviet Union a calamity because it imposed international borders on the Russians. "Do you think it's normal that 25 million Russian people were abroad all of a sudden? Russia was the biggest divided nation in the world. It's not a problem? Well, maybe not for you. But it's a problem for me"12. Problems are meant to be solved. But how might Russia solve this problem (for itself) of so many Russians-and even more Russian speakers-beyond its borders?

12 V. Putin in Charlie Rose, All Eyes on Putin, 27 September 2015, http://www.cbsnews.com/ news/vladimir-putin-russian-president-60-minutes-charlie-rose/ [accessed: 28.10.2015]. 
Since the end of the Cold War, Russia has used every political instrument at its disposal to influence and, from its perspective, support Russians and Russianspeakers beyond Russia's borders. Even in the early 1990s, Russia sought, through the threat of armed force, to coerce the Baltic States-particularly Latvia and Estonia, which had and still have substantial Russophone minorities- and to provide the Russians living in their territories with citizenship gratis, i.e. without meeting the legal requirements. Russia at that point still had its old Soviet garrison forces in the Baltic States and threatened that it would not withdraw them-that is, it threatened to occupy Latvia and Estonia-unless those Baltic States bowed to its will. In this context, the Russian military even "openly rehearsed and discussed invasion scenarios for the Baltic States", even though it was doubtful that the condition of the Russian army would have even permitted such an operation to occur $^{13}$. Although neither Latvia nor Estonia succumbed to Russian coercion in this instance, and were supported by counter-pressure from the United States and the Conference on Security and Cooperation in Europe against Russia to withdraw its forces from the region, Latvia was nonetheless obliged to accept thousands of demobilised Soviet soldiers, primarily retired officers, who had chosen to make Latvia their primary civilian residence before the collapse of the Soviet Union due to its comparatively higher standard of living.

More recently, Russia did employ force in the name of ethnic Russians, Russophones, or Russian citizens. In 2008, after a deliberate passportification campaign in which thousands of South Ossetians received Russian passports, Russia waged war against Georgia in the guise of humanitarian intervention. Since 2014, it has been involved in Ukraine in the name of defence of ethnic Russians and Russophones.

Russia has used the media to connect Russians and Russian speakers abroad to Russia itself, including in the Baltic States. Russia has employed financial leverage, funding organisations such as the Russkiy Mir Foundation, Russian politicalcultural centres, and national Russian political parties in the Baltic States, again to connect Russians and Russian speakers to Russia and to turn them into Russian political instruments. "The political and media spheres in Latvia are closely

13 P. Ito, Baltic Military Cooperate Projects: A Record of Success [in:] T. Lawrence, T. Jermalavičius (eds), Apprenticeship, Partnership, Membership: Twenty Years of Defence Development in the Baltic States, Tallinn, 2013, p. 249. 
intertwined, at least in the case of Russian-language media. The aims of both the media and politicians have often been similar: to create a unified bloc of voters and consumers who are expected to act in certain ways and to take on certain values"14. Russia's aim through its use of media is to exacerbate differences of perspective between the Balts and the Russians on emotional issues which range from shared Baltic-Russian history to contemporary foreign policy. Russia uses its soft power specifically to preserve these weaknesses and divisions in the Baltic States ${ }^{15}$. One Russian journalist, Pavel Baev, charitably suggests that although "Russia's track record of relations with Latvia and Estonia was rather chequered... [i]t was highly significant that Moscow refrained from exploiting the discontent in Latvia, which was hit most painfully by the economic crisis" ${ }^{\prime 16}$. Yet this one instance of restraint is hardly comforting given Russia's previous-as well as subsequent-attempts to influence events and policy-making in the Baltic States.

Russia has also sought political influence in the Baltic States through more direct means, including the energy sector, corruption, intelligence, and cyber activities. As the Baltic States are still largely reliant on the old Soviet energy network infrastructure, Russia has a potentially significant coercive instrument to use against them-and has already used it. However, it has rarely actually been effective in gaining Russia the political consequences which it desires ${ }^{17}$. The infamous cyber attacks which struck Estonia in May 2007 over the move of the bronze soldier statue may be the highest profile Russian attempt at coercively influencing a Baltic State-higher profile even than the military attempts of the early 1990s-but it was hardly the only case. Indeed, an almost successful case occurred in 2003-4 when "elements of Russia's intelligence services and organised crime syndicates (interrelated factors in Russia) infiltrated the electoral campaign of a presidential candidate, Rolandas Paksas, and later also his staff during his

14 A. Cheskin, Russian Speakers in Post-Soviet Latvia: Discursive Identity Strategies, Edinburgh, 2016, p. 77.

15 A. Grigas, Legacies, Coercion and Soft Power: Russian Influence in the Baltic States, Chatham House Briefing Paper, 2012, p. 13.

16 P.K. Baev, The Russian Army as a crumbling keystone in the European security architecture [in:] R. N. McDermott, B. Nygren, C. Vendil Pallin (eds), The Russian Armed Forces in Transition: Economic, geopolitical and institutional uncertainties, London, 2012, p. 103.

17 K. Smith Stegen, Deconstructing the 'energy weapon': Russia's threat to Europe as case study, Energy Policy, 39, 2011, p. 6511. 
short presidency." Fortunately, Lithuania's democratic institutions prevailed and Paksas was impeached ${ }^{18}$.

The Baltic States cannot comfortably remain bereft of a collective defence because Russia has repeatedly proven itself to be willing to use any and every instrument of statecraft up to and including armed force in pursuit of its policy goals, which include the protection of Russians and Russian speakers outside Russia by re-incorporating them into the motherland. This emphasis on ethnicity and language as a basis for conquest is not new to Russian foreign policy. Russian cartographers during the age of the tsars, such as Pyotr Keppen (1793-1864) and Rodrikh Erkert (1821-1900), realised that a cartographic emphasis on language induced ambiguity, blurred boundaries, and justified Russian frontier expansion westward into east central Europe. They also contributed to this effort through their own cartographical work ${ }^{19}$.

Throughout the eighteenth century, the Russian Empire turned this cartographical ruse into imperial policy. It tried to claim Latgale, then a province of Poland but later Latvia's easternmost region, based on false allegations that the population was in fact Belorussian, was therefore culturally Russian, and had only been separated from Russia by Polish conquest. This perspective was eventually broadened to include the generally Slavic populations of Poland, and culminated in the partitions of Poland which wiped it off the map of Europe by the nineteenth century $^{20}$. In the most recent decade, Russia has, on multiple occasions, blurred state borders through its emphasis on ethnicity and language, and subsequently violated state borders using force in the name of Russians and Russian speakers living outside Russia-including four discrete military presences in Abkhazia, South Ossetia, Crimea, and the Donbas. Because Russia now has a contemporary record of acting in this manner, such an eventuality is a clear danger-although not yet necessarily a direct threat-to the Baltic States.

18 J. Šleiytè, Russia's European Agenda and the Baltic States, New York, 2010, p. 146.

19 S. Seegel, Mapping Europe's Borderlands: Russian Cartography in the Age of Empire, Chicago, 2012, pp. 118, 147.

20 A. Plakans, A Concise History of the Baltic States, Cambridge, 2011, p. 139. 
Whether or not Russia will again violate state borders through force, specifically with regard to the Baltic States, has become the decisive question for NATO. Russia's victims in this regard, Georgia and Ukraine, aspired to membership in Western international institutions such as the EU and NATO, but their paths to the West were set awry by Russian military action. The Baltic States are different. Whereas Georgia and Ukraine dithered about whether to orient toward Russia or Europe for the better part of one or two decades, all three Baltic States pushed immediately, hard, and consistently for acceptance into Western political and security institutions, until they achieved their goals in 2004. Perhaps decisively, this push and eventual success occurred while Russia was relatively weak or otherwise constrained-first by its traumatic economic collapse in the 1990s and then by Putin's attempt to forge an actual constructive relationship with George W. Bush and the United States in the early 2000s.

Since the accession of the Baltic States to NATO and the EU (one of the great nails in the coffin of good West-Russia relations), Russia has sought to limit and stymie Western influence in what it considers its near abroad. Displeased with the EU's description of these aggregate regions as a "common neighbourhood", the Kremlin sees in the EU's naïvely un-geopolitical perspective an insidious plot to further the reversal of Russian fortunes since the collapse of the Soviet Union. Having first lost its influence in the Warsaw Pact states in favour of the West, Russia then definitively lost the Baltic States as well. Western protestations that they harbour no ill will against Russia cannot be believed in Moscow because, regardless of Western intention, Western policies have changed the geopolitical landscape to Russia's disadvantage.

The EU's identification of not just Moldova, Belarus, and Ukraine but even the three south Caucasus states of Georgia, Armenia, and Azerbaijan as part of a common neighbourhood for both the EU and Russia could only be judged from Moscow as a continuation of the trend of expanding Western influence into regions where Russia had once reigned supreme ${ }^{21}$. Russia's policies for limiting further Western influence have included aggression to pre-empt potential near or distant future EU and NATO membership for Georgia and Ukraine. This same policy nearly resulted in a direct clash between Russian and NATO troops at

21 Šleiytè, Russia's European Agenda and the Baltic States, 53. 
Pristina airport in Kosovo in 1999. However, to date, Russia has not yet aimed outright to reverse Western influence once it has been established by institution, as in the Baltic States. Perhaps Moscow does not intend to do so, or perhaps it has not yet had an opportunity to do so. Yet the risk to the Baltic States may skyrocket if the EU and NATO begin seriously again to consider admitting Ukraine and/ or Georgia, despite recent Russian actions-aggressive wars-arguably intended to prevent this from happening. At such a point, Russia may feel that it has nothing to lose by outright military challenge to NATO, as in any case it would then be on the cusp of losing any hope of having a sphere of influence, losing its status as a great power, and being left wide open to what it considers to be insidious Western political influences.

Besides the two questions of ethnic Russians and Russian-speakers and of a forceful Russian reaction to further NATO or EU expansion, Russia has historically pursued a very clear policy of territorial aggrandizement in the eastern Baltic littoral. Historically, whenever Russia has not owned the eastern Baltic littoral, it has always aimed to do so and followed policies designed to bring this objective closer to fruition. Russian motives for repeatedly pursuing a policy which places it on the eastern shores of the Baltic Sea have varied over time. In early centuries, it sought economic benefit from dominating the region of the Baltic States. Russian interest in the eastern Baltic littoral has persisted since before German missionaries, merchants, and crusaders first appeared in 1180 and began their century long quest of the region, but actively grew only from the late $15^{\text {th }}$-early $16^{\text {th }}$ century reign of Ivan III of Muscovy onward. Russia has fought numerous wars over the centuries to bring the region under its domination. Early on, Russian interest was primarily about prestige and economy-the right to demand and collect tribute from the indigenous peoples, and later to take advantage of the Hanseatic trading cities which emerged on those Baltic shores.

After the First World War, the economic aspect dried up due to political factorsprimarily because the newly-established Soviet Union had no interest in trading with the West-but security replaced economic concerns as the prime motivator for conquest. The recently incorporated Baltic States were heavily militarised by the Soviet Union during the Cold War because they represented the Union's only direct border with the Western world (save for a short border with Norway in the far north). With the collapse of the Soviet Union, Russia lost this heavily militarised 
border as its territory shrank to that of three centuries ago. The Moscow Military District transformed from being "the deep rear of Russia" into Russia's "advanced western defence line"22. Security is clearly a salient policy concern for Russia today, and its continued interest in the Baltic States runs along those lines, mixed with the ethnic Russian element.

Someone somewhere beyond the Kremlin surely has divined the right answer about Russian intentions-but the world as a whole will never know until the event itself comes to pass. The absence so far of a Russian move into the Baltic States is not evidence that it will not come eventually (this also being one of the fundamental difficulties of attempting to effect deterrence). After all, the day before Russian Special Forces moved into Crimea in February 2014, a Russian invasion of that peninsula had also been a non-occurrence that no one in the West was anticipating. Days, months, years of non-invasion inevitably precede the one day defined by a resort to armed force by one polity against another. For this reason, defence is often considered to be 'insurance'. As noted, Russia's policies toward the Baltic States since their re-attainment of independence have been largely unfriendly. Moreover, Russia's policies to strengthen its armed forces in the region, including the February 2016 activation of the old Soviet elite $1^{\text {st }}$ Guards Tank Army, were most often made prior, rather than in reaction to, any NATO policies countering Russia. The unnecessary activation of the $1^{\text {st }}$ Guards Tank Army began in November 2014, although NATO had no stated intention of reinforcing the Baltic States at that point.

Moreover, if NATO does not visibly prepare for defence of the Baltic States, Russia may rightly or wrongly perceive this as a political message that the Baltic States will not be defended-that Article 5 will not be extended so far east and that NATO will not seriously retaliate, even if only in certain, 'ambiguous' situations. Or, as another alternative, the Kremlin may come to believe that either a swift overrunning or ambiguous takeover of the Baltic States may deter NATO from even trying, despite a pre-existing political intention to defend NATO's easternmost constituents. To crack open a theatre of operations which has been

22 J. Erickson, Russia will not be trifled with: Geopolitical facts and fantasies, Journal of Strategic Studies, 22(2-3), 1999, p. 243. 
locked up is a difficult task, and every potential route back into the Baltic States would be arduous for NATO.

This would be the case particularly if Russia adopts recent notions, continuously under debate, of employing nuclear weapons as an instrument of de-escalation to deter NATO from considering a campaign to liberate reoccupied Baltic States ${ }^{23}$. Russian nuclear strategic thought is anything but coherent. The debate has been conducted almost without regard for the actual capabilities of the Russian nuclear forces and whether or not those forces could implement these ideas, if they were ever actually officially adopted. The Russian government has yet to show any indication that it is prepared to adopt any concept of nuclear strategy discussed in Russian strategic discourse, including the most dangerous idea of nuclear de-escalation. Nuclear de-escalation may appear counterintuitive to Western audiences, but the logic is clear, although it represents a strategic gamble for Russia. In brief, the argument is that a Russian nuclear strike, even at battlefield level, would break the will of the opposing polity to continue the war. Applied to the Baltic States, it would suggest that once the Baltic States were overrun, Russia would launch a limited nuclear strike against a further NATO target to break NATO's will to actually retaliate and liberate the Baltic States from Russian occupation. In the Baltic context, this may be an effective strategy if ever implemented, given how difficult it has been for the European Union just to maintain sanctions on Russia after its occupation of Crimea. Russian military exercises and war games in the recent past have sometimes culminated in simulated nuclear attacks, such as against Warsaw or the Copenhagen Strait, although the intelligence on these incidents is not always clear.

These are hypothetical futures for which there is no known evidence one way or the other, for or against. There is only Russian history, both distant and recent, to indicate Russian perspectives toward NATO, geopolitics, and the future. Yet the overall tenor of potential future interaction between the West and Russia seems unfortunately clear. There may exist no single action-or non-action-available to the West which is more likely to deter or prevent war than to provoke it. This is the second horn of the dilemma which NATO has faced since March 2014.

23 J.W. Kipp, Russia's Nonstrategic Nuclear Weapons, Military Review, 81(3) , 2001, pp. 27-39; D. Adamsky, If War Comes Tomorrow: Russian Thinking About "Regional Nuclear Deterrence”, Journal of Slavic Military Studies, 27(1), 2014, pp. 163-188. 


\section{NATO's Choice: Working as Intended?}

The West is confident in its ability to deter. Michael Howard once suggested that "we have become rather expert at deterrence" as a result of the Cold War experience ${ }^{24}$. NATO may have faced its dilemma in Baltic defence only subconsciously, unaware that deterrence might fail before its very inception. Nevertheless, at its summit in Warsaw in July 2016, NATO made a choice which favours one horn more than the other. Although it is not (yet, perhaps) committed to deploying significant heavy forces to the region, NATO has decided upon establishing a multinational battalion in each of the three Baltic States, as well as in Poland and has further, albeit temporarily, enhanced its presence in the region in response to Russia's Zapad-2017 exercise. The military value of these battalions will not be high, their size alone precluding them from putting up a credible defence of the Baltic States against the armed forces of Russia's Western Military District. Their value lies in their role as a multi-national tripwire for any invasion, thereby automatically involving a number of other NATO armed forces in the defence of the Baltic States from the very outset and putting NATO's credibility as an alliance wholly on the line. This suggests that NATO is willing to pursue the route of deterrence and, if necessary, defence rather than leaving the Baltic States militarily at the mercy of a revisionist Russia.

Is NATO's choice having the desired deterrent effect? One must, of course, acknowledge that it is impossible to know. The basic reason why NATO has been suffering a dilemma is also why we cannot know whether NATO's choice is working: we cannot peek into Putin's mind or that of any of his trusted advisors. Any public utterance or demonstration of peaceful intentions may be genuine, or may also be a ruse to mask hostility, and the Russian leadership certainly has not been trustworthy in the recent past. Nevertheless, public statements by the Russian leadership should be considered.

Putin has on at least two occasions since the annexation of Crimea rejected the notion of war with NATO. In a June 2015 interview with the Italian newspaper $I l$ Corriere della Sera, he asserted "that only an insane person and only in a dream

24 M. Howard, Lessons of the Cold War, Survival 36(4), 1994-95, p. 164. 
can imagine that Russia would suddenly attack NATO" and that such actions are groundless fear mongering ${ }^{25}$. More recently in an interview with Bloomberg Businessweek, Putin argued along similar lines. "I think all sober-minded people who really are involved in politics understand that the idea of a Russian threat to, for example, the Baltics is complete madness. Are we really about to fight NATO? How many people live in NATO? About 600 million, correct? There are 146 million in Russia." He went on to consider and disregard the possibility of nuclear war for the Baltic States, from Russia's perspective as the largest nuclear power ${ }^{26}$. What is interesting about these interviews is that he does not single out the Baltic States for mention except in the wider context of war with NATO as a whole. One might suggest, if Putin was actually being truthful in these interviews, is that NATO's choice is having the desired effect. That is, Putin considers NATO's defence commitment to the Baltic States to be credible, and therefore will not employ military means to further Russian political goals in the three Baltic countries. It is often suggested that Putin understands only force and respects only strength. His calculations of population suggest that he may recognise that NATO is far stronger than Russia. Perhaps Putin simply fears the current burst of NATO solidarity and seeks to mollify the alliance so that it does not further strengthen its presence on Russia's borders.

Other Russians do single out the Baltic States and declare that they must be the next target. This includes the infamous Duma member Vladimir Zhirinovsky, often seen as a Kremlin proxy to test public reaction to more radical policy suggestions, who has repeatedly hurled invective and threats at the Baltic States ever since they regained independence. Given Zhirinovsky's potential ties with the Kremlin, Putin's comments may be pure misdirection. Why highlight and unnecessarily foreworn a potential target of one's intentions? His statements may mollify those in NATO who are already predisposed toward forgiving and forgetting Russian aggression in Ukraine and who may not be wholly willing to expend the resources

25 L. Fontana, Vladimir Putin, interview to the Italian newspaper «Il Corriere della Sera»", Il Corriere Della Sera, 7 June 2015, http://www.corriere.it/english/15_giugno_07/ vladimir-putin-interview-to-the-italian-newspaper-corriere-sera-44c5a66c-0d12-11e58612-1eda5b996824.shtml [accessed: 21.09.2016].

26 J. Michlethwait, The Russian president on the future of Europe, why he's bullish on Gazprom, and the coming U.S. election, Bloomberg Businessweek, 8 September 2016, http:// www.bloomberg.com/features/2016-vladimir-putin-interview/ [accessed: 21.09.2016]. 
to contribute to even a token allied force in the Baltic States. Putin may be telling the truth, or he may be trying to lull NATO into a sense of complacency about Baltic defence. Perhaps NATO's response to Russian actions since February 2014 has been beyond Putin's expectations, and he feels that he must split NATO's members up as much as possible before his next act of aggression, through incessant disinformation, the financial sponsorship of pro-Kremlin parties throughout Europe, and so on. Russia has also been consistently expanding its armed presence near the Baltic States since 2014, through the activation of the $1^{\text {st }}$ Guards Tank Army as well as the reformation of two divisions.

Finally, President Trump may be a wildcard in the issue, as he alternately berates NATO and especially its European constituents, and then sends officials to reaffirm the credibility of Article 5. Furthermore, he personally appears to desire a close and warm relationship with Russia, but is blocked in this endeavour by the US Congress. Thus, it is unclear how much influence, for good or ill, Trump may have on NATO's past decisions or Russia's perceptions going into the future. However much high level policy appears to sway unsteadily in Trump's hands, implementation of NATO's collective decision from the Warsaw Summit in July 2016 has hardly been altered at all on the ground.

Ultimately, it is impossible to know whether or not Russia has truly been deterred by NATO defence policy regarding the Baltic States. Uncertainty reigns concerning both Russian intentions and the future. In this context of uncertainty, the political, strategic, and even moral imperative is to follow prudent policies. NATO, as the main guardian of the current status quo which so favours the West, is a status quo alliance. It is a defensive alliance. The consequences for which NATO policies should aspire in the name of prudence are those which protect the status quo through deterrence, if possible, and defence, if necessary. As Bernard Brodie argued during the Cold War about waging nuclear war, "[s]o long as there is a finite chance of war, we have to be interested in outcomes; and although practically all outcomes would be bad, some would be much worse than others" ${ }^{27}$.

It is in NATO's interest to avoid a defensive war in Europe without sacrificing anything if at all possible, through achieving effective deterrence. Failing that, it is

27 B. Brodie, The Anatomy of Deterrence, World Politics 11(2), 1959, p. 178. 
in NATO's interest to fight and defend the Baltic States. Many have speculated on the consequences to NATO and the EU of failing to protect the Baltic States from potential Russian aggression. The gravest consequence would be the loss of trust and solidarity among alliance and/or union members, which may potentially lead to the break-up of either or both organisations. It is prudent to attempt to create a deterrent relationship with Russia, it would be prudent to fight to defend the Baltic States, so that the current form and integrity of the Western world may be preserved. Even if many consider it unthinkable, NATO should be prepared for adverse outcomes to its current policies. It should be prepared actually to wage war if necessary. NATO has made its choice in the defence policy dilemma which it confronted in the name of Baltic defence. It remains to be seen how the beast behind the horns of the dilemma will react in the long-term.

\section{Bibliography}

Adamsky D., If War Comes Tomorrow: Russian Thinking About "Regional Nuclear Deterrence", Journal of Slavic Military Studies, 27(1), 2014.

Åselius G., Soviet Naval Perceptions of the Baltic Sea, 1938-41 [in:] M. H. Clemmesen, M. S. Faulkner (eds), Northern European Overture to War, 1939-1941: From Memel to Barbarossa, Leiden, 2013.

Baczyńska G., Szary W., Russia says will retaliate if U.S. weapons stationed on borders,

Reuters 15 June 2015, http://www.reuters.com/article/2015/06/15/us-russia-usaeurope-idUSKBN0OV17A20150615 [accessed: 28.10.2015].

Baev P.K., The Russian Army as a crumbling keystone in the European security architecture [in:] R. N. McDermott, B. Nygren \& C. Vendil Pallin (eds), The Russian Armed Forces in Transition: Economic, geopolitical and institutional uncertainties, London, 2012.

Barrass G.S., The Great Cold War: A Journey Through the Hall of Mirrors, Stanford, 2009. Bērziña I., Color revolutions: Democratization, Hidden Influence, or Warfare?, Riga, 2014.

Brodie B., The Anatomy of Deterrence, World Politics, 11(2), 1959.

Cheskin A., Russian Speakers in Post-Soviet Latvia: Discursive Identity Strategies, Edinburgh, 2016.

Cimbala S.J., Revisiting the Nuclear 'War Scare' of 1983: Lessons Retro- and Prospectively, Journal of Slavic Military Studies, 27(2), 2014.

Erickson J., Russia will not be trifled with: Geopolitical facts and fantasies, Journal of Strategic Studies, 22(2-3), 1999. 
Fontana L., Vladimir Putin, interview to the Italian newspaper «Il Corriere della Sera», Il Corriere Della Sera, 7 June 2015, http://www.corriere.it/english/15_giugno_07/ vladimir-putin-interview-to-the-italian-newspaper-corriere-sera-44c5a66c-0d1211e5-8612-1eda5b996824.shtml, [accessed: 2.09.2016].

Gray C.S., Deterrence and the nature of strategy, Small Wars \& Insurgencies 11(2), 2000.

Grigas A., Legacies, Coercion and Soft Power: Russian Influence in the Baltic States, Chatham House Briefing Paper, August 2012.

Hooker Jr. R.D., Operation Baltic Fortress, 2016, RUSI Journal, 3(160), 2015.

Howard M., Lessons of the Cold War, Survival, 4(36), 1994-95.

Ito P., Baltic Military Cooperate Projects: A Record of Success [in:] T. Lawrence \& T. Jermalavičius (eds), Apprenticeship, Partnership, Membership: Twenty Years of Defence Development in the Baltic States, Tallinn, 2013.

Jukes G., The Military Approach to Deterrence and Defense in: M. McGwire, K. Booth, J. McDonnell, Soviet Naval Policy: Objectives and Constraints, New York, 1975.

Kipp J.W., Russia's Nonstrategic Nuclear Weapons, Military Review, 3(81), 2001.

Mastny V., How Able was 'Able Archer'? Nuclear Trigger and Intelligence in Perspective, Journal of Cold War Studies, 1(11), 2009.

Michlethwait J., The Russian president on the future of Europe, why he's bullish on Gazprom, and the coming U.S. election, Bloomberg Businessweek, 8 September 2016, http://www. bloomberg.com/features/2016-vladimir-putin-interview/, [accessed: 21.09.2016].

Milevski L., Deterring Able Archer: Comments Arising from Adamsky's Lessons for Deterrence Theory and Practice, Journal of Strategic Studies, 37(6-7), 2014.

Plakans A., A Concise History of the Baltic States, Cambridge, 2011.

Putin V., Being strong: National security guarantees for Russia, 29 February 2012, http:// archive.premier.gov.ru/eng/events/news/18185/, [accessed: 28.10.2015].

Rose C., All Eyes on Putin, 27 September 2015, http://www.cbsnews.com/news/vladimirputin-russian-president-60-minutes-charlie-rose/, [accessed 28.10.2015].

Seegel S., Mapping Europe's Borderlands: Russian Cartography in the Age of Empire, Chicago, 2012.

Šleiytė J., Russia's European Agenda and the Baltic States, New York, 2010.

Stegen K.S., Deconstructing the 'energy weapon': Russia's threat to Europe as case study, Energy Policy, 39, 2011. 